\title{
INTERNATIONAL LEGAL COOPERATION IN SPHERES OF CULTURE - IMPORTANT PART OF INTERNATIONAL RELATIONS
}

\author{
Nuriddin Mamajonov ${ }^{1}$
}

\begin{abstract}
This paper assesses the cultural and humanitarian spheres of the Republic of Uzbekistan in regards to International legal cooperation. The paper examines the influence of cultural and humanitarian spheres in international relations of the states, including Uzbekistan. The paper also contains a discussion of the, increasing role of Uzbekistan in the 'culture factor' in international politics. The legal base of the Republic of Uzbekistan, international legal documents, and the research works of domestic and foreign scholars, in areas such as culture, education, science, tourism, and medical science, provide the basis for the research.
\end{abstract}

JEL Classification Numbers: K33 DOI: http://dx.doi.org/10.12955/cbup.v4.796

Keywords: Law, Politic, Culture, humanitarian, relations, cooperation, development, globalization, agreement, international, research, multilateral, bilateral, analysis.

\section{Introduction}

Uzbekistan, from the start of independence, has chosen a development approach called 'the uzbek model'. Its success realized a rise in the gross domestic product by 4.5 times (Tashmukhamedova, 2013) and development in economic, social, and humanitarian spheres, during its independent years.

Most important factors in this success were the political, legal, social, and economic reforms implemented by the country. As President of the Republic of Uzbekistan, Karimov (2010) stated that, in spite of increasing globalization and changes in the world, Uzbekistan should evaluate its globally role, impartially and critically, and that Uzbekistan should meet and keep pace with the requirements of the world.

Powerful countries assist their goals and objectives with internal policies that promote cultural and humanitarian relations, and their international influence validates this point.

In the cultural and humanitarian sphere, such a process develops a country's future along with its national interests within the international legal framework, and this further strengthens the existing framework. Today, Uzbekistan's cooperation in cultural and humanitarian matters is becoming one of the most urgent tasks of the country.

In the concept of foreign policy for the Republic of Uzbekistan, the step-by-step development of international cooperation in the cultural and humanitarian spheres is one of the foreign policy objectives.

The country's cultural and humanitarian treaty base consists of more than 160 documents. On the basis of a thorough and accurate analysis and research, introduction of new positions is one of the main goals of learning cultural and humanitarian spheres in a bilateral and international legal cooperation.

The question arises regarding the need for special consideration of bilateral agreements in humanitarian matters relating to cultural and international legal cooperation.

\section{Methods}

A review was conducted of existing literature and educational materials in the cultural and humanitarian spheres on national and international levels.

In particular, the review examined the work of Saidov $(1985,1993,2003)$ and others who researched the legal cooperation of Uzbekistan with international organizations, including United Nations Educational, Scientific and Cultural Organization (UNESCO), and other international organizations.

\section{Results and Discussion}

The existing literature and educational materials showed that the theme of international legal cooperation in the cultural and humanitarian spheres on national and international levels is insufficiently studied. The research and the majority of the studies are of a multilateral nature.

\footnotetext{
${ }^{1}$ Nuriddin Mamajonov, The University of World Economy and Diplomacy, Tashkent, Uzbekistan, n.mamajonov@yahoo.de
} 
Saidov $(1985,1993,2003)$ contributed knowledge in matters of Uzbekistan's legal cooperation with international organizations, including UNESCO and other international organizations. Such research was about strengthening multilateral cooperation in cultural and humanitarian domains.

Individual researchers and scientists provided only general or selected approaches in cultural and humanitarian sphere of bilateral international legal cooperation (Borisov, 1963; Chirkin, 1997; Galenskaya, 1987; Khvatov, 1987; Kolosov \& Krivchikova, 2005; Meerts, 2008; Tikhomirov, 1996). For instance, the advisor of the director of the Netherlands institute of International Relations 'Clingendael', Meerts (2008) wrote in 'Culture and International Law: From Peace to Justice' about the international legal framework of cultural cooperation and bilateral relations between countries in this field, and how different cultures dealt with international law. Meerts also wrote of the how international law influences the rules and regulations of these cultures, and whether international law was an effective tool in protecting cultural heritage, especially during wartime. Among important questions asked at the Fourth Conference at The Hague Academic Coalition (HAC), Meert queried whether this law protected the heritage of cultures in a balanced way.

In addition, Kolosov and Krivchikova (2005) in their co-published educational material, 'The International Trade Law', allocated a separate chapter for scientific-technical and cultural cooperation of the international legal practice in the world on the basis of culture, education, and tourism.

Moreover, Melekhin (1968) in 'Cultural and scientific dialogue peoples. Legal regulation' and Khvatov (1987) in 'Legal forms of cooperation of the higher school of the socialist countries' carried out scientific research in specific areas of study of cultural and humanitarian spheres.

As a result, important tasks of the science are currently needed both at the international and national level of study. These include analysis and development of accurate scientific conclusions and recommendations in the scientific practice of cultural and humanitarian spheres of bilateral international legal cooperation, as well as their implementation, formation, and strengthening of the reforms necessary in the framework of cultural and bilateral international legal cooperation in the humanitarian sphere.

Bilateral international legal cooperation in cultural and humanitarian matters is important as a separate entity in the national and international arena and as a vital tool to protect the interests of the state, and thus, it is critical to understand for international law.

After years of relative neglect, culture now receives due recognition as a key factor in managing and resolving conflicts and disagreements. However, theorists and practitioners speak of conflict resolution using 'culture' in a bewildering and unhelpful variety of ways (Alberstein, 2007). Nonetheless, culture remains a dynamic and derivative form for adjusting conflict and disagreements.

Considering deep cultural and historical opportunities for the Republic of Uzbekistan are needed in basic research for assessing the existing international legal framework, further strengthening of existing opportunities and facilities is needed to develop specific recommendations for international relations of the country, with considerable contribution added to strengthen its position in foreign policy.

At the same time, to improve the country's bilateral and international legal cooperation in cultural and humanitarian matters, Uzbekistan's national legislation should be compared with international experience to identify and solve problems.

It should be noted that almost all government programs pay special attention to the development of international relations in cultural and humanitarian spheres.

Nevertheless, the study of the theory and practice of the government agencies (not only ministries and departments responsible for the international political and economic relations, but all other supporting non-governmental organizations) should improve the country's multilateral and bilateral international relations in cultural and humanitarian spheres.

Another important factor in the study on this subject is the possibility of creating a new branch in international law in this country, using a single database for signed bilateral interstate, intergovernmental, and interagency treaties and agreements with foreign countries in cultural and humanitarian spheres. 
There remains a burning issue to create scientific skills based on terminology and concepts widely practiced within international legal agreements for the cultural and humanitarian matters of the country.

Furthermore, identifying new scientific skills and concepts of international law in Uzbekistan provides a theoretical basis, practical introduction, and an introduction to the scientific-theoretical understanding of international law.

\section{Conclusion}

The research results provide the fundamental understanding into the science of international law, as well as its practical applications. The theory, along with a comprehensive analysis of the materials with comparative tables and lists, could advance subjects, such as International law, Political science, and Cultural studies at undergraduate and graduate levels, and Jurisprudence and International law at secondary specialized educational institutions of Uzbekistan.

Overall, the selected topics in this paper are important for developing foreign policy of the Republic of Uzbekistan, and especially to protect and sustainably develop the country and its national interests in the international arena.

Finally, such research provides outcomes that can be used by Uzbekistan to further its strategy and position in cultural perspectives.

\section{References}

Alberstein, M. (2007). Forms of Mediation and Law: Cultures of Dispute Resolution. 22 OHIO State Journal of dispute resolution, pp.321.

Borisov K. G. (1963). International legal questions of recognition of foreign qualifications (nostrification) in the relations between the socialist countries. Soviet Yearbook of International rights. pp 214-219.

Chirkin V. E. (1997). Konstitutsionnoe pravo zarubezhnykh stran [Constitutional Law of Foreign Countries]. Moscow.

Galenskaya, L. (1987). Legal questions of the international cooperation in culture. L, pp.93-166.

Karimov, I. (2010). The concept of further deepening of democratic reforms in the country and developments of civil society. Tashkent, pp. 17-145.

Khvatov, V. Y. (1987). Legal forms of cooperation of the higher school of the socialist countries // jurists set. 2, 31-34.

Kolosov, Y. M. \& Krivchikova, E. S. (2005). Mezhdunarodnoe parvo [The International Trade Law]. In Moscow: Mezhdunarodnye otnoshenia [International Relationships]. Moscow: MGIMO University.

Melekhin, B. I. (1968). Cultural and scientific dialogue peoples. Legal regulation. Voronezh, S. 157-187.

Meerts, P. (2008). Culture and International Law (From Peace to Justice Series). New York, Cambridge University Press. Saidov, A. (1985). Typology and classification of the legal systems of contemporary. Pravovedenie, pp. 52-56.

Saidov, A. (1993). Comparative jurisprudence and legal geography of the world. pp. 15-33.

Saidov, A. (2003). Comparative Law. pp.59-65.

Tashmukhamedova, D. (2013, April 22). National Development Strategy of Uzbekistan. EMBASSY OF UZBEKISTAN TO THE UNITED STATES, Uzbekistan. Retrieved from http://www.uzbekistan.org/press/archive/1885/?print=1

Tikhomirov, Y. (1996). Comparative jurisprudence. Moscow: Norma. 